\title{
MIDAS
}

Museus e estudos interdisciplinares

\section{Matthew Mackisack - Discoveries: Art, Science \& Exploration [exposição]}

Matthew Mackisack

\section{(2) OpenEdition}

\section{Journals}

Electronic version

URL: http://journals.openedition.org/midas/928

DOI: $10.4000 /$ midas.928

ISSN: 2182-9543

Publisher:

Alice Semedo, Paulo Simões Rodrigues, Pedro Casaleiro, Raquel Henriques da Silva, Ana Carvalho

Electronic reference

Matthew Mackisack, « Matthew Mackisack - Discoveries: Art, Science \& Exploration [exposição] », MIDAS [Online], 5 | 2015, Online since 03 December 2015, connection on 24 September 2020. URL : http:// journals.openedition.org/midas/928; DOI : https://doi.org/10.4000/midas.928

This text was automatically generated on 24 September 2020 .

\section{cc) (ஒ)}

Midas is licensed under a Creative Commons Attribution-NonCommercial-ShareAlike 3.0 International License 


\title{
Matthew Mackisack - Discoveries: Art, Science \& Exploration [exposição]
}

\author{
Matthew Mackisack
}

\section{REFERENCES}

Discoveries: Art, Science \& Exploration. 2014. Curated by Nick Thomas, Martin CaigerSmith, and Lydia Hamlett. Exhibition presented at Two Temple Place, London by the University of Cambridge Museums between the 31st January and the 27th April of 2014.

1 Being a selection from all eight museums of the University of Cambridge, which concern everything from archaeology to zoology, the diversity of objects on display in Discoveries is remarkable. Cultural artefacts, fossils, western fine art, and scientific instruments, all sit alongside one another. The curators have - for the most part, very effectively - grouped the things into themed sections: "Objects", "Inscriptions", "Illuminations", "Collections", and "Founders". The latter two themes in particular serve the admirably reflexive and selfcritical function of suggesting how these things come to be sat in glass boxes at all, with the backstories consistently relating the imbrication of scientific and colonial enterprise.

2 The dodo on display is a good example of this. Its remains, we are told, were gathered from a Mauritian swamp in the 1870 s by islanders under the command of a colonial administrator, who passed them to his brother Alfred Newton, Professor of Zoology and Comparative Anatomy, who wired them together. The skeleton cuts a melancholy figure: guilelessly thick bones stained brown from the swamp, it speaks the human's capacity to exploit and dominate - its own members as much as the natural world.

If the exhibition effectively gives a sense of the human relationships behind the establishment of collections, another, more abstract relationship is intriguingly unresolved: that between 'art' and 'science'. The two cultures, the curators claim, are "mutually engaged" in "making visible" or "bringing to light". But curatorial choices and contextual information consistently bely this happy equality. Science in Discoveries 
is always the master discourse; art - here meaning 'visual representation' - is variously presented as science's laudatory servant, or as the miscomprehension of science, or what results when science fails. The capacity for art to be critical of the negative aspects of scientific endeavour, meanwhile, is actively repressed.

To take one example, An Allegorical Monument to Sir Isaac Newton (1727-1729) is an eccentric combination of the classical, the Christian, and the modern, as if the artists (or rather the commissioner, Irish opera impresario Owen McSwiney, whose instructions were strict) are trying their best to get a handle on the incipient Newtonian world and can only do so by aligning it with the old - and, as ironized in Pope's couplet, by making Newton divine. The scene is a cathedral, with vaulted ceiling and towering columns, arranged around a miracle: an urn containing Newton's ashes emits a beam of light which is refracted through two prisms into a rainbow. An angel gestures towards the miraculous beam, as if it is the Annunciation; but then Minerva, and personifications of Truth and Mathematics, also look on.

5 The artists neither know how to place Newton or understand his achievements. As the information panel is quick to remind us, the beam of refracted light is "scientifically incorrectly coloured". Consequently the painting only "suggests, rather than illustrates" the fact that white light is made up of different colours. We have, then, the sad situation that a tribute to the discoverer of the scientific nature of light itself fails to depict that nature. 'Artistic licence' just means getting the facts wrong.

6 Contemporary artist Sophy Rickett's light-flecked deep black discs, made while in residence at the University's Institute of Astronomy, are reprints from negatives produced by the Institute's camera telescope. They are not straight prints from the negatives, however: during development, the artist intuitively intervened in the process, in order to alter the resultant images. The intervention in the development of the prints - which lost them their scientific value, as indexical registrations of light from distant suns - was the intervention of what scientific technique does its best to eliminate: the subjective. Where the unadulterated print would have imparted the sublime wonders of the cosmos, Rickett's prints impart Rickett, and a human picturemaking capacity. This art, then, is produced from corrupted science, and is a lesser knowledge accordingly.

7 Another work made by a contemporary artist embedded in the museums, Brook Andrew's The Island I (2008) depicts, on a large red reflective surface, a hemispherical structure before a background of trees, which, the information panel tells us, is an Aboriginal burial mound, blown-up from an illustration in a forgotten 19th century encyclopaedia. The artist is a native Australian who searches anthropological collections for signs of his ancestors culture, and as far as the text is concerned, Andrew "creat[es] spectacular monuments to indigenous sites and arts of the nineteenth century".

8 But this is not what this picture is. Attention to the actual form of what is depicted suggests otherwise: this aboriginal architecture looks weirdly neo-classical, like one of Étienne-Louis Boullée's cenotaph designs. Then one realises what's happening, and why Andrew has recreated it in the form he has. The original image showed not a native Australian burial mound but the fantasy of a global European Enlightenment projected onto it. Hence the rendering in fluttering, reflective foils, pointing out the original to be the fanciful wishfulfilment that it is. Andrew's critical gesture is succinct. The 
spectacular monument this art makes is to the failure of historical science's treasured objectivity, and to the shadows cast when science "brings to light".

9 Most affecting in Discoveries - and where artistic and scientific endeavour do seem united - are the letters from Alfred Haddon, founder of the School of Anthropology, to his young son Ernest, describing his experiences in the Torres Strait in 1889. "Twice we asked some people to dance for us", writes Haddon in one, "and this is what they looked like and how they danced, instead of a piano someone beat a drum." There follows his own careful, unmannered drawings of the islanders. The letters' warmth is not only owed to their being written for a child. Haddon had arrived in the Torres Strait a zoologist, intending to study the coral reefs, but, captivated by the human inhabitants he encountered, left an anthropologist. The letters issue from - are really accounts of - a conversion, and, in light of what Haddon would go on to do, the beginning of a path that leads to Discoveries itself.

Haddon's letters aside, what Discoveries points to is a consistent problem with how 'art' and 'science' appear beside one another, not only in the museum but more generally as well. Their presentation as partners in enlightenment obscures the actual imbalance of power, where, as we have seen, art is merely non-science, serving only to communicate science's findings or celebrate its achievements. The curatorial challenge - to allow art like Brook Andrew's to do its critical work - remains.

\section{AUTHORS}

\section{MATTHEW MACKISACK}

University of Exeter Medical School, United Kingdom, mmackisack@googlemail.com 